\title{
KEPADUAN WACANA LISAN TALK SHOW INDONESIA LAWYERS CLUB (ILC) SECARA KOHESIF
}

\author{
Baiq Ningsum Ilham ${ }^{1}$; Sumarlam ${ }^{2}$; Diah Kristina ${ }^{2}$ \\ ${ }^{1}$ Mahasiswa S2 Linguistik Deskriptif Universitas Sebelas Maret, Surakarta, Indonesia \\ ${ }^{2}$ Guru Besar Fakultas Ilmu Budaya Universitas Sebelas Maret, Surakarta, Indonesia \\ ${ }^{3}$ Dosen Fakultas Ilmu Budaya Universitas Sebelas Maret, Surakarta, Indonesia \\ ${ }^{1}$ insun.mutmainnah89@gmail.com
}

\begin{abstract}
This research aims at describing (1) The grammatical aspects in the spoken discourse of ILC talk show, (2) describing lexical aspects in the spoken discourse of ILC talk show, (3) describing the coherence of the spoken discourse supported by the grammatical and lexical aspects in the ILC talk show.

This research was a descriptive qualitative study. The data source in this research was in the form of LC talk show broadcast. The data collection techniques of this research included observation and note-taking. The data analysis technique included distributional method followed by the technique of switch and deletion.

This research shows that the spoken discourse of ILC talk show was a cohesive discoure as it was supported by grammatical and lexical cohesion devices. In this spoken discourse, four aspects of grammatical cohesion were found, namely reference, substitusion, ellipsis, and conjunction. The most dominant grammatical cohesive device to be found was reference, used up to 1092 times $(64,19 \%)$. It is followed by conjuction, 519 (30,515\%); substitution, 62 (3,64\%), and ellipsis, 28 (1,64\%). Besides the grammatical cohesion aspects, lexical cohesion aspects in the spoken discourse ILC talk show were also invented. These included repetition, used 214 times (66,66\%); synonym, 24 (7,47\%); antonym, $28(8,72 \%)$, collocation, $16(6,92 \%)$, hyponym, $20(6,23 \%)$, and equivalence, $21(6,54 \%)$.

Each of the cohesion aspect, either grammatical or lexicalcohesion, has its own role in forming the text of spoken discourse, therefore the spoken discoursecould be arranged well and cohesively. Therefore, a study of spoken discourse needs to be done because it is an important aspect that forms the structure of a discourse born
\end{abstract}

Key words: gramatical aspects, lexical aspect, spoken discours, Indonesia Lawyers Club (ILC) talk show.

\section{PENDAHULUAN}

Wacana lisan yang merupakan wacana yang disampaikan dengan media lisan,. Hal ini sesuai dengan pendapat Mulyana, (2005: 53) menyatakan bahwa "Wacana lisan (spoken discourse) adalah jenis wacana yang disampaikan secara lisan atau langsung dengan bahasa verbal. Adanya kenyataan bahwa pada dasarnya bahasa pertama kali lahir melalui mulut/lisan. Wacana lisan dapat digunakan sebagai sarana komunikasi untuk mengungkapkan dan menyampaikan segala sesuatu yang menjadi buah pikiran, dan perasaan dalam bentuk ide,gagasan, ataupun 
pendapat.Wacana lisan dapat disampaikan secara langsung bertatap muka maupun disampaikan melalui media, misalnya televisi, radio, maupun telfon.

Wacana yang disampaikan dengan media lisan dapat dipakai dalam berbagai jenis kegiatan, salah satunya dapat dipakai dalam sebuah acara talk show. Oleh karena itu, talk show dapat dikategorikan sebagai wacana lisan. Proses terjadinya wacana lisan dalam percakapan talk show juga tidak terlepas dari hubungan antar bagian wacana yaitu hubungan bentuk yang disebut kohesi dan hubungan makna yang disebut koheren (Sumarlam, 2013: 23).Kohesi atau kepaduan wacana ialah keserasian hubungan antarunsur yang satu dengan unsur yang lain dalam wacana, sehingga terciptalah pengertian yang koheren(Haliday: 4).Kohesi juga merupakan hubungan yang diciptakan sebagai hasil ketika interpretasi suatu unsur tekstual bergantung pada unsur lain di dalam teks (Renkema, 1993: 35).

Dengan kata lain, kajian kohesi mengindikasikan bahwa makna yang digambarkan di dalam teks adalah makna yang diinterpretasikan oleh penutur dan petutur berdasarkan kesimpulan yang mereka buat tentang hubungan proposisi yang melandasi apa yang diujarkan.

Talk show yang merupakan sebuah program televisi atau radio di mana seseorang ataupun grup berkumpul bersama untuk mendiskusikan berbagai hal topik dengan suasana santai tapi serius, yang dipandu oleh seorang moderator.Kadangkala, talk show menghadirkan tamu berkelompok yang ingin mempelajari berbagai pengalaman hebat.Salah satu program talk show yang merebut perhatian khalayak pemirsa luas adalah tayangan Talk Show Indonesia Lawyers Club (ILC)di TV One. (Karni,http://id.wikipedia.org/wiki/Karni_Ilyas)

Talk show ILC adalah sebuah program Talk show yang dikemas secara interaktif dan apik untuk memberikan pembelajaran hukum bagi para pemirsanya.

Talk show ILC sebagai objek kajian karena talk show ini merupakan salah satu bentuk wacana lisan yang tidak terlepas dari pemakaian penanda kohesi yang banyak dan padat yang merupakan syarat keutuhan wacana dan kepaduan pendukung terjadinya wacana lisan tersebut.

Secara umum, alasan dipilihnya Talk show ILC sebagai objek kajian karena Talk show ini merupakan salah satu bentuk wacana lisan yang tidak terlepas dari pemakaian penanda 
kohesi yang banyak dan padat yang merupakan syarat keutuhan wacana dan kepaduan pendukung terjadinya wacana lisan tersebut. Setelah peneliti dengar dan perhatikan, ternyata dalam Talk show tersebut ditemukan banyak pemakaian berbagai penanda kohesi gramatikal dan leksikal yang dapat mendukung kepaduan dan keutuhan wacana lisan Talk show itu sendiri .

Sementara itu, alasan khusus dipilihnya talk show ILC karena talk show tersebut merupakan salah satu jenis talk show yang menghadirkan pakar-pakar ternama, mulai dari pengamat-pengamat ternama, pakar bidang lain, dosen, mahasiswa, bahkan pejabat yang terkait dengan topik yang diangkat. Sehingga sering memungkinkan terjadi perdebatan diantara orangorang yang pakar dibidangnya serta berkompeten untuk mengomentari persoalan-persoalan aktual yang menjadi topik diskusi dan sangat memungkinkan terjadi fenomena kebahasaan di dalamnya.

Analisis wacana lisan dalam acara talk show ILC, khususnya pada tanggal 23 September 2014. Dalam proses talk show ini akan di perlihatkan bagaimana sebenarnya struktur penggunaan bahasa yang para politisi gunakan. Dengan demikian, peneliti ingin meneliti piranti kebahasaan yang digunakan oleh partisipan dalam talk show tersebut khususnya dari aspek gramatikal dan leksikal, serta untuk mengetahui kepaduan wacana lisan berdasarkan penggunaan penanda kohesi gramatikal dan leksikal yang digunakan.

\section{TEORI DAN METODOLOGI}

Penelitian inimerupakan penelitian deskriptif kualitatif dan menggunakan pendekatan analisis wacana. Lokasi pada penelitian ini adalah demografis, tempat dari penelitian ini adalah di lokasi penayangan Talk show ILC di studio TV One. Partisipannya adalah semua partisipan yang terlibat melakukan percakapan wacana lisan dalam acara talk show ILC. Kejadian yang diteliti adalahpercakapan wacana lisan selama acara talk show ILC berlangsung sampai selesai.Sumber data pada penelitian ini berupa siaran talk show ILC pada tanggal 23 September 2014 di TV One.Data dalam penelitian ini ialah wacana lisan talk show Indonesia Lawyers 
Club (ILC) yang (sudah direkam sebelumnya) dan hasil review dari penelitian terdahulu. Penelitian ini menggunakan tehnik analisis dokumen.

\section{HASIL PENELITIAN}

Dalam penelitian ini, sesuai dengan yang tertera pada landasan teori ditemukan bahwa penanda kohesif terdiri dari aspek gramatikal dan aspek leksikal.

\section{Aspek Gramatikal Wacana Lisan Talk Show Indonesia Lawyesr Club (ILC)}

Aspek gramatikal yang ditemukan dalam penelitian ini berupa, refrensi, substitusi, elifsis dan konjungsi.Sedangkan aspek leksikal berupa, repetisi, sinonim, antonim, hiponim, kolokasi dan ekuivalensi. Aspek gramatikal yang berupa refrensi terdiri atas pronomina persona, pronomina demonstratif dan pengacuan komparatif. Pengacuan persona direalisasikan melalui pronomina persona I, pronomina persona II dan pronomina persona III.Pronomina persona I ditemukan data berupa satuan lingual yang ditandai dengan adanya kata " $a k u$, saya, ku, kami, dan kita". Masing-masing data pada kata tersebut berjumlah: Satuan "aku" berjumlah 10 buah data, "saya" berjumlah 220 data, "ku" berjumlah 4 data, "kami" berjumlah 17 data, dan "kita" berjumlah 118 data. Sehingga jumlah keseluruhan data pronomina persona I sebanyak 369 buah data. Pronomina persona II ditemukan data berupa satuan lingual yang ditandai dengan adanya kata "anda, kau, mu, dan kalian".Masing-masing data pada kata tersebut berjumlah: Satuan "anda" berjumlah 13 buah data, "kau" berjumlah 2 data, "mu" berjumlah 1 data,"kalian" berjumlah 1 data. Sehingga jumlah keseluruhan data pronomina persona II sebanyak 17 buah data. Pronomina persona III ditemukan data berupa satuan lingual yang ditandai dengan adanya kata "dia, ia, beliau,-nya, dan mereka". Masing-masing data pada kata tersebut berjumlah: Satuan "dia" berjumlah 63 buah data, "ia" berjumlah 6 data, "beliau" berjumlah 5 data, "nya" berjumlah 69 data, dan "mereka" berjumlah 5 data. Sehingga jumlah keseluruhan data pronomina persona III sebanyak 140 buah data. Secara keseluruhan jumlah data pronomina persona (I,II,III) sebanyak 534 data. 
Pronomina demonstratif ditemukan berupa; pronomina demonstratif waktu dan pronomina demonstratif tempat. Pronomina demonstratif waktu direalisasikan melalui waktu "kini, lampau, dan y.a.d,dan waktu netral".Data pronomina demonstratif waktu“kini” berjumlah 41 data, waktu "lampau" berjumlah 61 data, waktu "y.a.d" berjumlah 19 data, dan waktu "netral" berjumlah 4 data. Sehingga jumlah keseluruhan data pengacuan demonstratif berjumlah125buahdata. Sedangkan untuk pronomina demonstratif tempat direalisasikan melalui "demonstratif tempat dekat dengan penutur, agak jauh dengan penutur, jauh dengan penutur, dan tempat eksplisit".Pronomina demonstratif tempat "dekat dengan penutur" ditemukan data berjumlah 142 data, "agak jauh dengan penutur" berjumlah 247 data, "jauh dengan penutur" 0 data dan " tempat eksplisit" sebanyak 24 data. Sehingga jumlah keseluruhan data demonstratif tempat berjumlah 413 buah data. Secara keseluruhan jumlah data pengacuan demonstratif berjumlah 540 data.Pengacuan komparatif dalam penelitian ini direalisasikan melalui satuan lingual "seperti, dengan, berbeda dengan, berbeda halnya",yangmenunjukkan "bentuk/ wujud,sikap, sifat, prilaku,dsb.Satuan lingual "seperti” berjumlah 9data, "dengan' berjumlah 7data, "berbeda dengan" berjumlah 2 data,dan "berbedahalnya" berjumlah 1 data. Sehingga jumlah keseluruhan pengacuan komparatif sebanyak 21 buah data.

Aspek gramatikal kedua berupa substitusi, direalisasikan melalui substitusi nominal berjumlah 24 data, substitusi verbal 11 data, substitusi frasal 16 data, substitusi klausal 18 data. Sehingga jumlah keseluruhan data substitusi sebaanyak 69 data.Aspek gramatikal ketiga berupa elifsis, yang direalisasikan melalui elifsis "kata" sebanyak 16 data, elifsis "frasa" berjumlah 9 data, elifsis klausal berjumlah 3 data. Sehingga jumlah data elifsis keseluruhan sebanyak 28 data.Sedangkan aspek gramatikal keempat yang berupa konjungsi,direalisasikan melalui konjungsi"sebab"sebanyak 64 data, "akibat"35 data, "perlawanan 45data, "perlebihan"1 data, "pengecualian"3 data, "konesif" 22 data, "tujuan" 22data, "penjumlahan" 132data, "pemilihan" 22 data, "harapan" 22 data, "perturutan" 30 data, "waktu" 34 data, "syarat 27 data, "kecaraan" 41 data, "perincian"2 data, "pengandaian" 23 data, dan "pemelengkap 14 data. Sehingga jumlah keseluruhan data konjungsi sebanyak 519 data. 
Dari jumlah rincian data penelitian yang diperoleh di atas, dapat ditunjukkan dalam tabel jumlah keseluruhan data aspek gramatikal wacana lisan talk show Indonesia Lawyers Club (ILC) sebagai berikut.

Tabel 1: Jumlah Keseluruhan Penggunaan Aspek Gramatikal

\begin{tabular}{cccc}
\hline No & $\begin{array}{c}\text { Rekapitulasi Aspek } \\
\text { Gramatikal }\end{array}$ & Jumlah & \% \\
\hline 1 & referensi (pengacuan) & 1092 & 64,19 \\
2 & substitusi (penyulihan) & 62 & 3,64 \\
3 & elifsis (pelesapan) & 28 & 1,64 \\
4 & konjungsi (perangkaian) & 519 & 30,51 \\
\hline & Jumlah & 1702 & 100 \\
\hline
\end{tabular}

Berdasarkan tabel rekapitulasi jumlah keseluruhan pemakaian aspek gramatikal pada wacala lisan talk show ILC di atas, terlihat bahwa aspek gramatikal berupa pengacuan atau referensi yang paling banyak digunakan yakni berjumlah sekitar 1092 (64,19\%) data. Disusul dengan penggunaan aspek gramatikal berupa konjungsi sebanyak 519 (30,51\%) data. Sementara data substitusi berjumlah $62(3,64 \%)$, dan yang paling sedikit digunakan berupa aspek gramatikal jenis elifsis dengan jumlah hanya $28(1,64 \%)$ data. Penggunaan aspek gramatikal berupa pengacuan yang paling banyak digunakan disebabkan karena pada wacana lisan talk show tersebut terdapat banyak partisipan dan masing-masing partisipan lebih cendrung menggunakan kata ganti persona daripada menggunakan penyebutan nama partisipant secara langsung.

\section{Aspek Leksikal Wacana Lisan Talk Show Indonesia Lawyers Club(ILC)}

Aspek leksikal yang ditemukan dalam penelitian ini berupa, repetisi, sinonim, antonim, kolokasi, hiponim, dan ekuivalensi. Aspek leksikal pertama, yang berupa repetisi terdiri atas, repetisi "epizeuksis"berjumlah 55data, repetisi "tautotes" 6data, repetisi "anafora"36data,repetisi "epistrofa" 36data,repetisi "mesodiplosis" 35 data, repetisi "epanalepsis" 10 data,repetisi "anadiplosis" 25 data,repetisi "mesodiplosis" 35 data dan repetisi "penuh/utuh" 11 data. Sehingga jumlah keseluruhan data repetisi berjumlah 214 data. Aspek leksikal kedua berupa sinonim, yang direalisasikan melalui sinonim "kata dengan kata, kata dengan frasa atau sebaliknya, frasa dengan frasa". Sinonim "kata dengan kata" ditemukan data 
sebanyak 10 data, sinonim "kata dengan frasa atau sebaliknya" sebanyak 6 data, dan "frasa dengan frasa" sebanyak 8 data. Sehingga jumlah keseluruhan data sinonim dalam wacana lisan talk show ILC, sebanyak 24 buah data.

Aspek leksikal ketiga ditemukan berupa antonim atau oposisi, yang direalisasikan melalui oposisi "mutlak" sebanyak data, oposisi "kutub" 2 data, oposisi "hubungan" 3 data, oposisi "hirarkial" 6 data dan oposisi "majmuk" 2 data. Sehinggajumlahdata antonim/oposisi keseluruhan berjumlah 28 data.Aspek leksikal keempat berupa hiponim yang memiliki data sebanyak 16 buah data. Aspek leksikal kelima berupa kolokasi yang memiliki data sebanyak 72 data. Dan aspek leksikal keenam berupa ekuivalensi yang memiliki data sebanyak 21 data. Sehingga jumlah keseluruhan data yang ditemukan untuk pennada aspek leksikal sebanyak 365 data. Dari jumlah rincian data penelitian yang diperoleh di atas, dapat ditunjukkan dalam tabel jumlah keseluruhan data aspek leksikal wacana lisan talk show Indonesia Lawyers Club (ILC) sebagai berikut.

Tabel 2: Jumlah Penggunaan Aspek Leksikal

\begin{tabular}{cccc}
\hline No & Aspek Leksikal & Jumlah & \% \\
\hline 1 & Repetisi & 214 & 66,66 \\
2 & Sinonimi & 24 & 7,47 \\
3 & Antonimi & 14 & 3,72 \\
4 & Kolokasi & 72 & 19,92 \\
5 & Hiponimi & 20 & 6,23 \\
6 & Ekuivalensi & 21 & 6,54 \\
\hline & Jumlah & 365 & 100 \\
\hline
\end{tabular}

Berdasarkan tabel di atas, terlihat bahwa jenis aspek leksikal berupa repetisi yang paling banyak digunakan dalam wacana lisan talk show ILC, dengan jumlah data 214 (66,66\%). Hal ini disebabkan karena wacana talk show termasuk wacana lisan maka pengulangan penyebutan konstruksi tertentu sering diungkapkan, mengingat wacana lisan cendrung tidak terstruktur bentuk konstruksinya. Selain itu juga disebabkan karena tuturan yang diucapkan berebntuk satu topik, sehingga para partisipan talk show cendrung mengucapakn hal yang samadengan partisipan yang lain. 


\section{PEMBAHASAN}

Tersusunnya wacana lisan talk show secara kohesif, disebabkan karena hadirnya maanfaat dan fungsi masing-masing aspek kohesi sehingga tercipta menjadi sebuah wacana. Wacana lisan talk show ILC merupakan wacana yang mempertimbangkan aspek tersebut, sehingga wacana tersebut terdengar bermakna dan tidak ambigu. Adapun aspek gramatikal yang terdapat pada wacana lisan talk show ILC ditemukan berupa referensi, substitusi, elifsis dan konjungsi.Berikut pembahasannya.

\section{Kohesi Gramatikal pada Talk Show Indonesia Lawyers Club (ILC)}

Ada beberapa karakteristik yang ditemukan dari hasil analisis data mengenai aspek gramatikal.Pertama, kohesi gramatikal yang terdiri atas empat aspek yakni refrensi, substitusi, elifsis dan konjungsi, ditemukan bahwa refrensi atau pengacuan paling banyak digunakan dengan jumlah data 1092 data.Hal tersebut disebabkan karena banyaknya partisipan yang hadir pada talk show. Sehingga untuk penyebutan nama, penunjukan nama tempat digunakan kata ganti sebagai keefektifan wacana dan untuk menghindari penyebutan kembali nama-nama partisipan secara berulang-ulang maka para partisipan menggunakan penanda pengacuan pronomina persona, demonstratif dan komparatif.

Kedua, pada aspek refrensi tersebut, ada yang mengacu secara endofora dan ada juga yang mengacu secara eksofora, baik yang bersifat endofora anafora maupun yang bersifat endofora katafora.Sehingga pengacuan tersebut menciptakn wacana lisan menjadi unik dan variatif.

Ketiga, penggunaan pronomina personapada wacana lisan ini tidak seperti penggunaan pronomina persona pada wacana jenis lain, pada wacana jenis ini, pronomina persona digunakan dengan mempertimbangkan usia, dan dengan siapa berbicara, sehingga pronominal persona yang digunakan disesuaikan. Berbeda dengan penggunaan pronomina persona pada wacana jenis lain yang secara umum menggunakan pronomina persona secara monoton dan tanpa mempertimbangkan usia. 
Keempat, pada wacana lisan talk show ini, unsur acuan pronomina yang bersifat eksofora hanya dapat diketahui dan disimpulkan berdasarkan pemahaman terhadap konteks wacana, khususnya konteks situasi. Unsur kohesi berupa pengacuan bersifat eksofora dalam wacana lisan talk show ini diwujudkan dalam bentuk pronomina -nya dan mereka yang mengacu secara eksoforis pada keadaan/situasi, orang, atau hal-hal tertentu yang berada di luar teks atau tidak disebutkan sebelumnya secara jelas dan tertulis di dalam teks, seperti terlihat pada nomor data (TWLT: N97:K82/A.1.1/31) dan (TWLT: N101:K16/A.1.1/341)

Kelima, pada wacana lisan talk show ini, ditemukannya pronomina demonstratif sebagai pronomina yang mendominasi, yang direalisasikan melalui demonstrative tempat dan demonstratif waktu yang berjumlah 540 buah data. Dimana untuk sub aspek yang mendominasi adalah demonstratif tempat. Hal ini disebabkan karena adanya asal partisipan yang berbedabeda dan setiap partisipan menyebut sistim hukum yang berlaku ditempat masing-masing, maka secara langsung partisipan memberikan gambaran hukum sesuai dengan hukum yang berlaku ditempat mereka. Hal tersebut karena dua satuan penanda tersebut paling epektif untum penyebutan nama tempat secara langsung. Sebagai contoh di bawah disajikan contoh datanya.

(1) Arswendo Atmowiloto: Matilah saya disini. (TWLT: N142: K6/A.2/490)

Pada kutipan tersebut, pronomina 'di sini' mengacu pada tempat Arswendo sedang berada yakni di studio TvOne, tempat acara talk show berlangsung.

Keenam, aspek gramatikal berupa pengacuan komparatif dalam wacana lisan talk show ini berupa perbandingan umum dan perbandingan khusus, baik yang mengacu pada hal-hal yang tidak sama atau tidak serupa seperti kata 'berbeda halnya, tidak sama dengan, berbeda halnya dan berbeda dengan. Sedangkan perbandingan yang mengacu pada hal-hal yang sama atau halhal yang serupa seperti kata 'bagai, persis, dan seperti. Sebagai contoh sebagai berikut.

(2) Gede Pasek Suardika: Berbeda halnya ketika melihat tuntutan pencabutan hak untuk dipilih pada jabatan publik itu dalam perspektif sebagai warga negara. (TWLT: N110: K14/A.3/20) 
Pada kutipan tersebut terdapat satauan pembanding berupa frasa 'berbeda halnya' yang berfungsi membandingkan perbedaan antara hukuman yang dijatuhkan kepada tersangka korupsi yang tercatat sebagai warga negara dengan yang bukan warga negara dan memiliki hak pilih dan memilih sebagai jabatan tertentu sesuai dengan landasan pencabutan hak politik.

Ketujuh, aspek gramatikal berupa penyulihan atau substitusi, sub jenis substitusi nominal paling banyak digunakan dan jenis sub substitusi verbal paling sedikit jumlahnya dalam wacana lisan talk show ILC, yakni hanya sejumlah 11 buah substitusi. Hal ini bukan merupakan sebuah masalah karena pada dasarnnya penggunaan piranti kohesi disesuaikan dengan kebutuhan wacana, kebutuhan disini termasuk kebutuhan untuk memperjelas maksud dan tujuan pengungkapan sebuah wacana lisan.

Kedelapan,untukaspekgramatikal berupa pelesapan atau ellipsis ditemukan sebanyak 28 data yang direalisasikan dalam tiga jenis pelesapan yakni pelesapan kata, frasa dan pelesapan klausal. Ada tiga karakteristik yang dapat disimpulkan dari hasil analisis data mengenai aspek gramatikal jenis pelesapan ini. Karakteristik pertama, penggunaan aspek kohesi berupa pelesapan klausal dan farasal ditemukan dalam data berupa dialog, seperti pada data nomor (14) dan (21) pada lampiran elifsis. Ini menunjukkan bahwa pelesapan klausal dan frasal ditemukan khusus dalam wacana lisan . Sedangkan dalam wacana tulis, pelesapan jenis klausal dan farasal ini biasanya ditemukan pada dialog/percakapan atau dalam tulisan yang bersifat percakapan antar tokoh.Sebagai contoh terlihat pada data di bawah.

(3) Karni Ilyas: Ya kalau kita berartifikasi hukum konvensi internasional, kita menganggap yaitu hal yang berlaku untuk seluruh dunia. (TWLT: N70: K2/A.3/14)

Akhyar Salmi: Ya $\varnothing$, tapi apakah itu sudah dijadikan, di adopsi ke dalam hukum positif kita? Harus atau tidak. (TWLT: N71: K1/A.3/14)

Karakteristik kedua, pelesapan jenis kata ditemukan dalam wacana lisan ini tidak berbeda dengan jenis wacana lain, terbukti bahwa jenis pelesapan kata ini terjadi pada wacana yang berbentuk narasi maupun bisa juga terjadi pada wacana yang berbentuk dialog.Karakteristik ketiga, penghilangan kata-kata tertentu atau elifsis dalam wacana lisan talk 
show ILC tidak selalu dipentingkan dalam membentuk ikatan kohesi.Hal tersebut karena jika memahami konteks pembicaraan, maka wacana tersebut bisa difahami dan dimengerti.Sebagai contoh sebagai berikut.

(4) Karni Ilyas: Pariangan?Ø. (TWLT: N153: K1/A.3/22)

Pada kutipan di atas terdapat pelesapan kata berupa kata 'mana', dalam konteks ini Karni Ilyas menanyakan kelompok salah satu mahasiswa yang berasal dari pariangan, tetapi dalm hal ini host melesapkan kata mana dengan menggunakan kata introgasi. Contoh tersebut jika tidak dilesapkan akan tampak seperti

(5) Karni Ilyas: Pariangan? mana. (TWLT: N153: K1/A.3/22)

Kesembilan, aspek kohesi gramatikal yang berupa konjungsi atau perangkaian direalisasikan melalui 17 penanda kohesi. Yang jumlah keseluruhan datanya sekitar 519 buah data. Konjungsi tersebut berupa konjungsi 'sebab, akibat, perlawanan, perlebihan, pengecualian, konsesif, tujuan, penjumlahan, pemilihan, harapan, perturutan, waktu, syarat, kecaraan, perincian, pengandaian, dan pemelengkap.

Berdasarkan hasil analisis data, ada beberapa hal yang dapat disimpulkan mengenai aspek gramatikal jenis konjungsi atau perangkaian ini. Pertama, jenis konjungsi yaang paling banyak ditemukan dalam aspek gramatikal ini berupa, konjungsi penjumlahan (aditif) dengan jumlah 132 data. Hal tersebut disebabkan karena konjungsi ini berfungsi menjumlahkan beberapa kejadian pada kasus jabatan tertentu, dan jika konjungsi ini tidak digunakan maka wacana lisan kurang berterima dan kurang meyakinkan. Selain itu juga karena umumnya konjungsi penjumlahan lebih cendrung digunakan pada wacana lisan. Untuk konjungsi penjumlahan ini ditandai dengan adanya penggunaan satuan lingual berupa 'serta, dan, juga, selain itu juga, dan serta merta'.

Kedua, jenis konjungsi yang paling sedikit digunakan adalah konjungsi perlebihan (eksesif). Hal ini disebbakan karena dalam wacana lisan, konjungsi ini hanya berfungsi menegaskan sebagai alasan penguat dalam mengungkapkan argumen, seperti yang tampak pada 
contoh lampiran nomer (TWLT: N82: MK6/A.4/84). Selain itu juga karena merupakan jenis konjungsi yang jarang digunakan dalam komunikasi lisan.

\section{Aspek Leksikal pada Talk Show Indonesia Lawyer Club (ILC)}

Adapun pada aspek leksikal terdapat beberapa karakteristik yang ditemukan dari hasil analisis data.Repetisi yang merupakan pengulangan satuan lingual (bunyi, suku kata, kata, atau bagian kalimat) yang dianggap penting untuk memberi tekanan dalam sebuah konteks yang sesuai.Berdasarkan posisi dan letaknya dalam kalimat komunikasi partisipan, pada penelitian ini terdapat semua jenis repetisi terdapat kecuali repetisi simplok.Repetisi dalam penelitian ini ditemukan sebanyak 214 dan sekaligus sebagai aspek leksikal yang paling banyak digunakan.Hal ini dikarenakan karena pengulangan merupakan aspek penting dalam tuturan guna untuk membentuk wacana terdengar variatif. Adapun karakteristik yang ditemukan dalam repetisi ini, berupa; Pertama, repetisi yang ditemukan berupa kata, frasa, dan klausa. Dalam hal ini repetisi ditemukan dalam hal benda, tindakan, dan orang, yang memiliki fungsi untuk mempertegas topik yang sedang dibicarakan agar tujuan pembahasan mengenai pencabutan hak politik mengena kepada masing-masing pembicara yang hadir pada talk show ILC. Seperti misalnya yang repetisi dalam hal tindakan ditemukan repetisi berupa kata 'ancaman', (TWLT: N10: K23,24/B.1/31), yang menekankan arti penting sebagai bentuk tindakan untuk memberi pelajaran kepada yang terkena kasus hukum yang berlaku. Ancaman yang dimaksudkan adalah penjatuhan hukuman pencabutan hak politik bagi yang koruptor.

Jenis kohesi leksikal kedua berupa sinonim.Sinonim merupakan salah satu aspek leksikal untuk mendukung kepaduan wacana dan berfungsi menjalin hubungn makna yang sepadan antara satun lingual tertentu dengan satuan lingual lain dalam wacana.Dalam wacana lisan ini hubungan kemiripan makna atau hubungan berdekatan terjalin antara kata dengan kata, kata dengan frasa atau sebaliknya dan frasa dengan frasa. Sebagai contoh sinonim ini terlihat pada contoh kata ' khusus dan spesifik' (TWLT: N114: K23,24/B.2/19). Dalam konteks wacana, kedua kata ini memiliki makna yang sama, dan juga merujuk pada satu hal yang sama. 
Antonim disebut juga oposisi makna.Pada penelitian ini ditemukan 5 jenis oposisi makna yang terjalin melalui oposisi mutlak, oposisi kutub, oposisi hubungan, oposisi hirarkial dan oposisi majemuk. Oposisi-oposisi tersebut bertentangan maknanya dengan unsur satuan lain dalam kalimat. Di mana maknanya itu memiliki makna perbandingan atau pertentangan. Sebagai contoh berupa kata 'pro dan kontra', (TWLT: N156: K2/B.3/26). Kata-kata yang beroposisi tersebut berfungsi memberi kepaduan pada wacana lisan talk show.

Kolokasi atau sanding kata merupakan asosiasi tertentu dalam menggunakan pilihan kata yang cenderung digunakan secara berdampingan.Pada wacana lisan talk show ini menggunakan kolokasi semata-mata untuk memberi kejelasan komponen yang tercakup dalam hal perpolitikan atau dalam menjalankan tugas kenegaraan. Sebagai contoh, kata-kata yang memiliki kolokasi seperti kata 'rakyat, hukum, negara' (TWLT: N9: K5,6,8/B.5/2). Kata-kata tersebut cenderung digunakan secara berdampinga dalam satu ranah.Dalam hal ini, kata-kata tersebut digunakan pada domain atau jaringan tertentu yakni domain kenegaraan.Hampir pada setiap bentuk wacana yang padu dan utuh memiliki aspek leksikal berupa kolokasi tersebut.Hal tersebut tidaklah mungkin suatu wacana tersusun atas kata secara terpisah dan tidak tersusun sesuai komponen jaringannya.Diksi yang digunakan untuk memberi kolokasi pada tuturan wacana lisan secara berdampinga sesuai topikyang sedang dibicarakan menjadikan wacana utuh dan padu.

Hiponimi dapat diartikan sebagai satuan bahasa (kata, frasa, kalimat) yang maknanya dianggap merupakan bagian dari makna satuan lingual yang lain. Unsur atau satuan lingual yang mencakupi beberapa unsur atau satuan lingual yang berhiponim itu disebut "hipernim" atau "superordinat" . Pada penelitian ini, hiponim ditemukan dalam bentuk jalinan hubungan makna yang mencakupi unsur makna satuan lainnya.Jalinan makna tersebut berupa kata-kata yang merupakan kata yang memiliki ikatan semantis pada wacana lisan. Sebagai contoh terdapat kata 'undang-undang, pidana, saksi' (TWLT: N24: K9, 11, 12/B.4/7), yang memiliki hiponim makna yang digunakan oleh hakim. Bentuk kata hiponim ini dapat membentuk makna khusus 
atau spesifik.Kelompok kata tersebut dapat dikatakan sebagai pembentuk kepaduan wacana lisan.

Ekuivalensiadalah hubungan kesepadanan antara satuan lingual tertentu dengan satuan lingual yang lain dalam sebuah paradigma. Ekuivalensi ini merupakan aspek leksikal terakhir, yang tampaknya kosa kata yang digunakan berupa hasil afiksasi dari morfem atau bnetuk asal yang sama. Penggunaan bentuk ekuivalensi dalam wacana lisan memiliki hubungan yang sepadan seperti contoh kata 'pemilihan dengan memilih' (TWLT: N14: K5,6/B.6/1), memiliki arti yang sepadan yakni tentang adanya hak untuk melakukan suatu hak pribadi dalam menjalankan aturan hukum, yaitu yang berasal dari kata yang sama berupa kata 'pilih'. Kedua kata tersebut mengindikasikan adanya orang yang dipilih dan ada yang bertindak sebagai memilih.Adanya kata-kata yang berekuivalensi tersebut dapat membentuk kepaduan wacana lisan talk show.

\section{Kepaduan Teks dalam Hal Penggunaan Penanda Kohesi Gramatikal dan Leksikal} pada Wacana Lisan Talk Show Indonesia Lawyer Club (ILC)

Berdasarkan hasil analisis data, kepaduan mengenai adanya penggunaan kedua aspek kohesi gramatikal dan leksikal dalam wacana lisan talk show ILC, dapat dikatakan padu. Untuk lebih jelasnya,terlebih dahulu akan dipaparkan deskripsi mengenai jumlah dan persentasi kohesi gramatikal dan kohesi leksikal yang ditemukan dalam wacana lisan talk show ini. Pada tabel berikut ini dapat dilihat jumlah penggunaan setiap aspek kohesi tersebut.

Tabel 3: Gambaran Kepaduan Wacana Lisan Talk Show ILC

\begin{tabular}{cccccc}
\hline \multicolumn{3}{c}{ Aspek Gramatikal dan Leksikal pada Wacana Lisan Talk Show ILC } \\
\hline \multicolumn{3}{c}{ Aspek Gramatikal } & \multicolumn{3}{c}{ Aspek Leksikal } \\
\hline Jenis & Jumlah & $\%$ & Jenis & Jumlah & $\%$ \\
\hline referensi & 1092 & 64,1 & Repetisi & 214 & 66,66 \\
substitusi & 62 & 3,64 & Sinonim & 24 & 7,47 \\
Elifsis & 28 & 1,64 & Antonym & 14 & 3,83
\end{tabular}




\begin{tabular}{cccccc} 
konjungsi & 519 & 30,5 & Kolokasi & 72 & 19,72 \\
- & - & - & Hiponim & 20 & 6,23 \\
- & - & - & Ekuivalensi & 21 & 6,645 \\
\hline Jumlah & 1701 & 100 & Jumlah & 365 & 100 \\
\hline
\end{tabular}

Berdasarkan tabel di atas,dapat dilihat jumlahpenggunaan masing-masing sub aspek kohesi gramatikal dan leksikal dalam wacana lisan talk show ILC. Pada tabel tersebut terlihat bahwa jumlah aspek pengacuan atau referensi yang paling banyak digunakan daripada jumlah kemunculan tiga aspek gramatikal lainnya, yakni penyulihan, pelesapan, dan perangkaian. Banyaknya penggunaan aspek gramatikal berupa pengacuan dalam wacana ini dilatarbelakangi oleh beberapa faktor. Pertama, Karena wacana ini merupakan sebuah wacana yang berbentuk talk show yang berciri; (1) disampaikan dengan lisan,(2)berbentuk percakapan, (3) menghadirkan banyak partisipan, (4) mengangkat topik yang sedang aktual, dan (5) menghadirkan pakar ahli di bidang yang sedang dibicarakan. Oleh karena itu, pengungkapan kejadian-kejadian yang sedang dibicarakan dilakukan dalam bentuk dialog-dialog yang setiap partisipan diberi waktu giliran bicara, dan dengan partisipan yang relatif berbeda dari awal hingga akhir percakapan talk show. Sehingga untuk menghindari penyebutan kembali nama partisipan yang sama secara berulang, partisipan wacana lisan talk show lebih banyakmenggunakan pronomina persona, pronomina demonstratifdan pengacuan komparatif. Selain itu juga, dalam setiap percakapan disebutkan siapa yang menuturkan percakapan dan ditujukan kepada siapa, serta terdapat di mana pembicaraan topik tersebut, sehingga aspek pengacuan dapat ditemukan dihampir seluruh kalimat percakapan wacana lisan talk show.

Selain itu juga, faktor penyebab aspek 'pengacuan' paling banyak digunakan karena wacana lisan talk show mampu menujukkan ciri-ciri penyampaian, ciri percakapan dan menariknya topik yang diperbincangkan. Pada wacana lisan talk show ini, para partisipan berusaha untuk mengomentari persoalan sesuai pengalaman dan pengetahuan secara komprehensif melalui sistem perdebatan timbal balik antar pakar ahli dibidangnya. Hal ini 
dilakukan dengan cara menyebutkan bukti dan dasar hukum tertentu yang merujuk pada kasus yang sedang diperdebatkan secara berulang-ulang. Penyebutan bukti dan dasar hukum tersebut sebagai unsur acuan yang hampir selalu diikuti oleh penggunaan aspek pengacuan tersebut.

Dengan demikian, penyebutan dan perdebatan mengenai topik diperdebatkan dalam waktu yang panjang, sehingga para partsisipan talk show menyiratkan kepada pendengar, penonton, (pemirsa)bahwa 'pencabutan hak politik koruptor'yang dinyatakan dalam wacana lisan talk show merupakan sebuah proses hukum yang tegas, adil tanpa memandang bulu. Selain itu para partisipanjuga adalah orang-orang terkenal ahli di bidangnya dianggap sebagai orang-orang yang memiliki kebijakan publik dapat diajak bekerja sama dalam membela kebenaran hukum yang beralaku di wilayah tertentu.

Dengan kata lain, tanpa melalui komentar dan perdebatan serius dan jelas, maka para pejabat publik membiarkan masyarakat memahami sendiri bagaimana selayaknya hukum diberlakukan. Hal inilah yang menyebabkan banyaknya penggunaan pengacuan dalam wacana lisan talk show ILC digunakan.

Selanjutnya, talk show wacana lisan ILC juga berusaha menciptakan suasana atau situasi dalam percakapan talk show melalui penyebutan beberapa tempat secara ekplisit secara berulang-ulang. Penyebutan nama tempat eksplisit ini ditandai dengan satuan lingual penyebutan nama negara tempat hukum dan penjelasan hukum terdapat. Hal ini pula yang melatarbelakangi dominasi dari penggunaan kohesi gramatikal jenis pengacuan di dalam wacana lisan talk show ILC. Misalnya, dalam dialog-dialog pada wacana lisan ini secara berulang-ulang disebutkan nama negara seperti, Indonesia, Amerika, Afrika, dan Australian. Melalui penyebutan nama negara secara ekplisit ini , partisipant talk show berupaya untuk menarik perhatian pemirsa dengan mengetahui bagaimana situasi atau suasana yang terjadi dalam sistem perpolitikan di suatu negara, misalnya ketika tiba waktu dilakukannya demokrasi pemilihan umum untuk jabatan tertentu, maka para politisi mulai marak melakukan beberapa aktivitas dan aksi guna untuk mendapatkan kedudukan publik. Sehingga dengan demikian terjadi penyebutan nama negara secara berulang-ulang. Dengan cara ini, percakapan talk show 
ILC menyiratkan kepada masyarakat umum bahwa pejabatpublik berusaha menunjukkan kekuasaannya kepada para caleg tersebut. Dengan cara ini juga, masyarakat umum dapat memahami dan ikut merasakan situasi ketegangan yang terjadi di lokasi talk show.

Terdapat perbedaan dalam pemakaian aspek leksikal pada wacana lisan talk show ini yaitu, penggunaan aspek leksikal digunakan dalam jumlah yang sedikit dibandingkan dengan jumlah pemakaian aspek gramatikal, namun hal tersebut tidak mempengaruhi kepaduan wacana lisan talk show. Penggunaan penanda kohesi leksikal ini, juga memiliki tujuan; Pertama, dalam pengacuan leksikal berupa repetisi, terdapat penyebutan beberapa singkatan seperti 'KPK dan DPR', selain itu juga pada repetisi tersebut cendrung menyebut pengulangan yang bersifat nomina, verba frasa dan klausal secara berulang-ulang. Seperti telah dijelaskan pada alasan penggunaan kohesi gramatikal di atas, penggunaan aspek kohesi secara berulang atau repetisi ini bertujuan untuk mempertegas atau memperdalam pengetahuan tentang politik hukum melalui perdebatan, percakapn talk show serta mendeskripsikan suasana atau situasi perpolitikan di negara tertentu secara tajam dan berwawasan di dalam percakapan talk show.

\section{KESIMPULAN}

Pada wacana lisan talk showIndonesia Lawyers Club(ILC) ditemukan empat aspek kohesi gramatikal, yaitu referensi, substitusi, ellipsis, dan konjungsi. Kohesi gramatikal ini didominasi oleh penggunaan aspek referensi atau pengacuan, yakni sebanyak 1092 pengacuan, yang terdiri atas pengacuan persona sebanyak 534, pengacuan demonstratif sebanyak 540, dan pengacuan komparatif sebanyak 21. Aspek berupa elifsis atau pelesapan merupakan aspek kohesi gramatikal yang paling sedikit jumlahnya dalam wacana lisan talk show ini, yakni sebanyak 28 elifsis. Aspek berupa substitusi sebanyak 62 dan konjungsi berjumlah 519 konjungsi yang direalisasikan melalui 17 sub konjungsi. Pada aspek konjungsi ini, konjungsi berupa penambahan (aditive) yang paling banyak digunkan karena konjungsi tersebut berfungsi menjumlahkan kasus yang ada dengan keterkaitannya dengan tersangka. 
Aspek kohesi leksikal yang dimanfaatkan untuk memperkuat kepaduan makna pada wacana lisan talk show adalah repetisi, sinonimi, antonimi, kolokasi, hiponimi dan ekuivalensi.Repetisi dalam wacana lisan talk show ILC terdapat 214, sinonim sebanyak 24 yang terdiri dari sinonim kata, frasa dan klausal, antonim sebanyak 14, kolokasi sebanayak 72 , hiponimi 20, dan ekuivalensi 21. Dari jumlah masing-masing sub aspek leksikal, ditemukan jumlah keseluruhan penggunaan aspek leksikal sebanyak 323. Dengan demikian, dapat dikatakan aspek kohesi leksikal mendukung kepaduan wacana.

Dengan terpenuhinya penggunaan aspek gramatikal dan leksikal pada wacana lisan talk show ILC tersebut, maka wacana lisan talk show layak disebut sebagai sebuah wacana.Masingmasing dari aspek gramatikal dan leksikal memiliki kegunaan yang sangat penting dalam membentuk kepaduan wacana lisan talk show, sehingga tersusun secara kohesif dan koheren.

\section{SARAN}

Penelitian ini merupakan penelitian awal mengenai analisis aspek gramatikal dan leksikal wacana lisan yang berbentuk talk show sehingga masih terdapat banyak kekurangan dan masih memerlukan tindak lanjut yang lebih komprehensif. Oleh karena itu diharapkan bagi peneliti lain untuk mengadakan penelitian-penelitian yang sejenis menyangkut analisis wacana guna untuk menyempurnakan hasil analisis penelitian wacana lisan selanjutnya.

\section{DAFTAR PUSTAKA}

Halliday, M. A. K\& Ruqaiya Hasan. 1976. Cohesion in English. London: Longman House.

Ilyas, Karni. 2014. http://id.wikipedia.Org/wiki/Karni Ilyas(diunduh pada tanggal 24 September 2014 pukul 09.00 WIB).

Mulyana. 2005. Kajian Wacana: Teori, Metode dan Aplikasi Prinsip-Prinsip Analisis Wacana. Yogyakarta: Tiara Wacana.

Renkema, Jan. 1993. Discourse Studies: An Introduction Textbook. Amsterdam/ Philadelphia: John Benjamins Publishing Company.

Sumarlam. 2013. Analisis Wacana. Teori dan Praktik Analisis Wacana.Surakarta: Buku Katta. 